Ann. For. Sci. 56 (1999) 511-520

\title{
Probability of germination after heat treatment of native Spanish pines
}

\author{
Adrián Escudero*, María Victoria Sanz, José Manuel Pita, Félix Pérez-García \\ Dept. Biología Vegetal, Escuela de Ingeniería Técnica Agrícola, Universidad Politécnica de Madrid, Madrid, 28040, Spain
}

(Received 6 April 1998; accepted 1 February 1999)

\begin{abstract}
Spanish pine forests exhibit a high degree of resilience to frequent wildfires. For this reason, they have been considered as active pyrophytes. However, the primary evidence of the fire response of some of the seven Spanish pines suggests that they are not real pyrophytes because germination enhancement has not been detected. In order to investigate the germination response of the Spanish pine seeds after heating, seeds were submitted to different treatments at varying temperatures $\left(50-130{ }^{\circ} \mathrm{C}\right)$ and exposure times ( $1-15 \mathrm{~min})$ to simulate responses to different fire regimes and situations. The probability of germination after heating was modelled by means of multiple logistic regressions using temperature, time and their interaction as predictors. Very predictive models were found for all the pines, except for Pinus pinea. Seeds germinate readily without treatment, losing their viability within a short time and showing a slight protection from fire. The results suggest that, despite the fact that these pines all occur in fire-prone environments, their germination behaviour has clearly not evolved in relation to fire alone. Furthermore, seed behaviour is not related to the general syndromes described as typical of fire-evolved plants. Whereas most of the Mediterranean seeders base their efficient recruitment after wildfires on the presence of hard-coated seeds, most of the Mediterranean pines have attempted other strategies with some variants related to prolific seed production. Only $P$. pinea regeneration after wildfires depends on the existence of fireresistant and hard-coated seeds. (@ Inra/Elsevier, Paris.)
\end{abstract}

heat treatments / Mediterranean pine forests / multiple logistic regression / seed germination / wildfires

Résumé - Probabilité de germination des graines de pins d'origine espagnole après traitement par chauffage. Les pins espagnols montrent un haut degré de résilience aux feux fréquents. Pour cette raison, ils ont été considérés comme des pyrophytes actifs. Cependant, l'évidence première de la réponse au feu de certaines des sept espèces de pins espagnols suggère qu'elles ne sont pas de réelles pyrophytes car aucune augmentation de germination n'a été observée. Afin de connaître la réponse à la germination des graines après chauffage, des graines furent exposées à différents traitements de gradients de température $\left(50^{\circ} \mathrm{C}\right.$ à $\left.130^{\circ} \mathrm{C}\right)$ et de durée (1 min à $15 \mathrm{~min}$ ) afin de simuler la réponse à différents régimes de situation de feu. La probabilité de germination après chauffage a été modélisée au moyen de régressions multiples logistiques utilisant la température, la durée d'exposition et leur interaction comme variables prédictives. De très bons modèles prédictifs ont été établis pour tous les pins, excepté pour Pinus pinea. Les graines germent déjà sans traitement, perdent rapidement leur capacité germinative et montrent une faible protection au feu. Les résultats suggèrent que, en dépit du fait que tous ces pins soient localisés dans un environnement propice à l'incendie, il est clair que leur comportement germinatif n'a pas uniquement évolué en relation avec les feux. En outre, le comportement des graines n'est pas relié au syndrome général décrit comme typique de l'évolution des plantes sous l'influence du feu. Alors que la plupart des semenciers méditerranéens basent leur efficiente régénération après passage du feu sur l'existence de graines à téguments épais, la plupart des pins méditerranéens ont établi d'autres stratégies avec des variantes reliées à une production prolifique de graines. Après incendie, seule la régénération de $P$. pinea dépend de l'existence de graines résistantes au feu et avec des téguments épais. (C Inra/Elsevier, Paris.)

chauffage / forêts de pins méditerranéens / régression multiple logistique / germination des graines / feu sauvage

* Correspondence and reprints
E-mail: adrianesc@bio.etsia.upm.es 


\section{Introduction}

As in other Mediterranean ecosystems, pine forests seem to exhibit a high degree of resilience to frequent wildfires [38, 40, 61]. For that reason, Mediterranean pines have been traditionally considered as 'active pyrophytes' $[1,2,10,28,30,31,54,57,59,65]$ and even their forests as 'fire type' or 'fire climax'. The reasons for this biological interpretation must be related to the fact that Mediterranean pine forests are particularly prone to periodic fires $[17,57]$, thousands of hectares being burnt every year around the Mediterranean basin. Pine forests are usually able to recover their former structure after wildfires [39]. Furthermore, the existence of some remarkable adaptive traits developed to couple with fire-induced disturbances such as seed retention in the canopy (serotiny) or xerochasic opening of the cones of some of them $[14,54]$, seem to indicate a clear evolutionary relationship between pines and fire. However, evidence of germination enhancement by fire in some of these pines is almost absent $[57,60]$ and the more realistic term 'adapted to fire' has been applied to them. In this sense, Lamont et al. [29] point out that of the 95 species in the genus Pinus only six species are considered obligatory pyriscent, although many of them are highly competitive in the post-fire environment. On the other hand, Mediterranean pines have long been considered photophilous generalist plants with a high capacity for spatial and biological selection to colonization after any type of disturbance $[3,4]$.

Recently, several authors have noted that some of these pines are not genuine pyrophytes $[15,36,46]$ because their germination is not stimulated by heat treatments as occurs in many other Mediterranean shrubs [13, $18,23,52,56,62,66,69]$. Furthermore, some difficulties in the re-establishment of some of these pines after intense fires have also been reported, as in the case of $P$. pinaster and $P$. halepensis (Escudero, per. obs.), $P$. pinaster in Portugal $[10]$ and $P$. nigra $[15,63]$.

Our main goal is to model the germination behaviour of the Spanish pines after heat treatments in order to establish the evolutionary relationships between pines and wildfires at this life stage. For that, seeds were subjected to different 'fire intensity' treatments at varying temperatures and exposure times to simulate responses to different fire regimes or microtopographic fire-driven heterogeneity [46]. The probability of germination after heating was modelled by means of logistic curves using temperature, exposure time and their interaction as predictors.

\section{Materials and methods}

\subsection{Short description of the pines}

Six of the 11 pine species naturally growing in Europe are present in the Iberian Peninsula. Most of these pines have been planted for timber or even for edible seeds for centuries; thus, in many cases the original boundaries of their distributions are not easily definitively established. $P$. halepensis Miller, $P$. pinea L. and $P$. pinaster Aiton are low-altitude pines widely distributed in the Mediterranean Basin. $P$. pinea is found mainly on sandy soils, whereas $P$. pinaster grows on acid soils and $P$. halepensis mainly on calcareous soils. On the other hand, $P$. uncinata Ramond ex DC. is a narrowly distributed sub-Alpine pine, confined to the Pyrenees and some isolated populations in the Sistema Ibérico range. $P$. nigra Arn. is a very variable Mediterranean pine which grows in the supra-Mediterranean and mainly on the oroMediterranean belts of the highest ranges of the eastern half of the Iberian Peninsula (biogeographical terms following Rivas-Martínez [48]). The Spanish populations have been ascribed to $P$. nigra Arn. subsp. salzmannii (Dunal) Franco. P. sylvestris L., a typical and widespread European pine, is basically a Spanish oroMediterranean and subalpine pine which reaches here its southern and western limits. Finally, $P$. canariensis Sweet ex Spreng, which is an endemic pine of the Canary Islands, was also included in the study.

\subsection{Experimental design}

Seeds were obtained from the Institute for Nature Conservation, Ministry of Environment (1995-1996 harvest). Seed provenances used in the present study were $P$. sylvestris from Soria province, $P$. nigra from Cuenca province, $P$. uncinata from Huesca province, $P$. pinea from Madrid province, $P$. pinaster from Albacete province, $P$. halepensis from Jaén province and $P$. canariensis from Tenerife Island. Seeds were stored at $6{ }^{\circ} \mathrm{C}$ in darkness in open containers. Seeds were submitted to different combinations of high temperatures and times in order to cover a wide range of conditions encountered by seeds during fires. Twenty heat treatments were carried out. Heat treatments were as follows: $50{ }^{\circ} \mathrm{C}(1,3,7,10$ and $15 \mathrm{~min}), 70{ }^{\circ} \mathrm{C}(1,3,7,10$ and 15 $\min ), 100^{\circ} \mathrm{C}(1,3,7$ and $10 \mathrm{~min}), 130^{\circ} \mathrm{C}(1$ and $3 \mathrm{~min})$ and $150^{\circ} \mathrm{C}$ ( 1 and $3 \mathrm{~min}$ ). A control treatment was also carried out. Parameters of the control were included in the models as $20{ }^{\circ} \mathrm{C}$ and $1 \mathrm{~min}$ of exposure time. Germination tests for each heat treatment were performed with 100 seeds in four Petri dishes $(9 \mathrm{~cm}$ in diameter) on two filter papers moistened with distilled 
water. The dishes were placed in controlled environmental cabinets at an alternating temperatures of $15{ }^{\circ} \mathrm{C} / 25^{\circ} \mathrm{C}$ with a $16 \mathrm{~h}$ light $/ 8 \mathrm{~h}$ dark photoperiod (Osram fluorescent tubes L20 W/105, 30-45 $\mathrm{Em}^{-2} \mathrm{~s}^{-1}$ ). The criterion of germination was visible radicle protusion. Germination was checked daily and the germinated seeds were removed. After 30 days the experiments were concluded.

\subsection{Data analysis}

As in most of the cases the difference in final percentage was very slight among the lowest intensity treatments (control, $50{ }^{\circ} \mathrm{C} / 1 \mathrm{~min}, 70{ }^{\circ} \mathrm{C} / 1 \mathrm{~min}$ and $100^{\circ} \mathrm{C} / 1$ min treatments), the Kaplan-Meier method was adopted to estimate germination functions due to right censored data. The shape difference in the modelled germination curves was tested by the non-parametric logrank test [45]. When necessary, differences in the final percentage of germination were evaluated by means of the G-test.

Logistic regressions $[21,27]$ were performed to determine whether either of the two variables considered were predictors of the germination probability. We tested models with the two variables (temperature and time) and their interaction, and also tested all the reduced models. Logistic relationships are of the following form:

$$
p=\frac{1}{1+\mathrm{e}^{-z}}
$$

where $p$ is the probability of germination and $Z$ is a linear combination of the variables included in the model. The coefficients of $Z$ are estimated by maximization of the likelihood function. Our hypothesis tests are based on the change in the -2 log likelihood ratio after building models with and without variables $[19,21,67]$. The goodness of fit of each model is evaluated by means of the classification table and tested by the model chisquare improvement test. All the models included in table $I$ were highly significant $(P<0.0005)$. The relevance of each variable in the models, including interactions, was tested by means of the likelihood ratio test as recommended by Hosmer and Lemeshow [20] and its partial contribution to the model evaluated by the $\mathrm{R}$ statistic. Three criteria were weighted in order to select the final models for each pine: the maximum percentage of overall correctly classified seeds, the minimum $-2 \log$ likelihood ratio or deviance and simplicity [67].

\section{Results}

Seeds readily germinated without heat treatment (control) in all cases, though some differences were detected between the seven pines $(\mathrm{G}=63.02$, d.f. $6, P<0.0001)$. Germinability ranged between $100 \%$ in the case of $P$. sylvestris to $70 \%$ in $P$. uncinata, the rest being above the $85 \%$ of $P$. pinea. The total number of germinated seeds in each treatment is presented in Appendix 1.

The shapes of the germination curves were compared within each species for the less intense treatments (control, $50{ }^{\circ} \mathrm{C} / 1 \mathrm{~min}, 70{ }^{\circ} \mathrm{C} / 1 \mathrm{~min}$ and $100^{\circ} \mathrm{C} / 1 \mathrm{~min}$ ). Three different patterns were detected (figure 1 ). The first appeared in $P$. pinaster for which no significant differences (log-rank test) were detected between the curves. $P$. halepensis, $P$. uncinata and $P$. sylvestris presented a second type of response which was based on the fact that control seeds germinate significantly faster than seeds submitted to any heat treatment. Finally, $P$. pinea, $P$. nigra and $P$. canariensis presented significant differences between treatments involving not only control seeds.

All the logistic models developed were highly significant $(P<0.0005)$ for each pine (table $I)$, except for $P$. pinea, with the number of overall correctly classified cases varying between $62.11 \%$ for $P$. halepensis and $89.47 \%$ for $P$. sylvestris. The models for $P$. pinea were not significant $(P=0.93$ for the best one). The number of germinated seeds in $P$. pinea was similar in each treatment (around $80 \%$ ), being only significantly different in the most severe treatment $\left(150{ }^{\circ} \mathrm{C} / 3 \mathrm{~min}\right)(\mathrm{G}=31.3$, d.f. $17, P=0.019-$ n.s. - after comparing all but this last treatment, and $\mathrm{G}=88.79$, d.f. $18, P<0.0001$ after including all the treatments). Contour graphs of the probability of germination for the other six pines are presented in figure 2 . The bold 0.5 isoline masks the line in the temperature $\times$ time space where the probability of germination is $50 \%$. Above this line, seeds have a chance to germinate.

\section{Discussion}

Spanish pines can hardly be considered as genuine pyrophytes, since a significant germination enhancement has not been detected after heating treatment in any of them. Nevertheless, the concept of pyrophyte is under revision at present, even for some Mediterranean plants such as Cistaceae or Leguminosae species described as classical examples of pyrophytes, because their germination has been experimentally proven to be stimulated by heat. Thus, in population dynamic terms, these Mediterranean plants are now considered heliophilous 
Table I. Parameters of the significant logistic models.

\begin{tabular}{|c|c|c|c|c|c|c|}
\hline Pine species & $\begin{array}{l}\text { Terms in } \\
\text { the model }\end{array}$ & $\begin{array}{c}-2 \mathrm{LL} \\
\text { (Constant) }\end{array}$ & $\begin{array}{l}-2 \mathrm{LL} \\
\text { (Model) }\end{array}$ & $\begin{array}{l}\text { Overall correctly } \\
\text { classified (\%) }\end{array}$ & Variables in the model & $\begin{array}{l}\text { Significance } \\
\text { R statistic }\end{array}$ \\
\hline \multirow[t]{6}{*}{ P. sylvestris } & $\mathrm{T}$ & 2545.66 & 1338.19 & 85.26 & $\mathrm{~T}=-0.397$ & 0.000 \\
\hline & $\mathrm{T}, \mathrm{t}$ & & 1252.03 & 89.47 & $\mathrm{~T}=-0.432$ & 0.000 \\
\hline & T. T*t & & 1187.12 & 89.47 & $\begin{array}{l}t=-0.174 \\
T=-251\end{array}$ & $\begin{array}{l}0.000 \\
0.000\end{array}$ \\
\hline & & & & & $\mathrm{t}=0.095$ & 0.000 \\
\hline & & & & & $\mathrm{T}^{*} \mathrm{t}=-0.138$ & 0.000 \\
\hline & $\mathbf{T}, \mathbf{T}^{*} \mathbf{t}$ & & 1216.04 & 89.47 & $\begin{array}{c}T=-450 \\
T * t=-.204\end{array}$ & $\begin{array}{l}0.000 \\
0.000\end{array}$ \\
\hline \multirow[t]{5}{*}{$P$. uncinata } & $\mathbf{T}$ & 2562.23 & 2088.85 & 66.95 & $T=-.355$ & 0.000 \\
\hline & $\mathrm{T}, \mathrm{t}$ & & 2088.20 & 66.95 & $\mathrm{~T}=-0.351$ & $\begin{array}{l}0.000 \\
0.420\end{array}$ \\
\hline & $T, t, T *_{t}$ & & 208237 & 66.95 & $\mathrm{~T}=-0.22$ & 0.000 \\
\hline & & & & & $t=0.02$ & 0.039 \\
\hline & & & & & $\mathrm{T} * \mathrm{t}=-0.038$ & 0.016 \\
\hline \multirow[t]{5}{*}{ P. nigra } & $\mathrm{T}$ & 2444.50 & 1840.56 & 79.95 & $\mathrm{~T}=-0.428$ & 0.000 \\
\hline & $\mathrm{T}, \mathrm{t}$ & & 1405.16 & 85.11 & $T=-0.438$ & 0.000 \\
\hline & $\mathrm{T}, \mathrm{t}, \mathrm{T} \boldsymbol{*}_{\mathrm{t}}$ & & 1393.87 & 85.11 & $T=-0.32$ & 0.000 \\
\hline & & & & & $t=-0.06$ & 0.002 \\
\hline & & & & & $\mathrm{T}^{*} \mathrm{t}=-0.06$ & 0.009 \\
\hline \multirow[t]{8}{*}{ P. canaeriensis } & $\mathrm{T}$ & 2128.03 & 1674.00 & 81.21 & $\mathrm{~T}=-0.405$ & 0.000 \\
\hline & $\mathrm{T}, \mathrm{t}$ & & 1667.59 & 81.21 & $\mathrm{~T}=-0.367$ & 0.000 \\
\hline & & & & & $\mathrm{t}=-0.045$ & 0.011 \\
\hline & $\mathrm{T}, \mathrm{t}, \mathrm{T}^{*} \mathrm{t}$ & & 1578.76 & 81.63 & $\mathrm{~T}=-141$ & 0.000 \\
\hline & & & & & $\mathrm{t}=0.044$ & 0.014 \\
\hline & & & & & $T^{*} t=-0.183$ & 0.000 \\
\hline & $\mathbf{T}, \mathbf{T} * \mathbf{t}$ & & 1645.43 & 84.47 & $T=-\mathbf{4 0 2}$ & 0.000 \\
\hline & & & & & $\mathrm{T} * \mathrm{t}=-0.111$ & 0.000 \\
\hline \multirow[t]{6}{*}{ P. halepensis } & $\mathrm{T}$ & 2449.05 & 2117.80 & 62.11 & $\mathrm{~T}=-0.323$ & 0.000 \\
\hline & $\mathrm{T}, \mathrm{t}$ & & 2101.95 & 62.67 & $\mathrm{~T}=-\mathbf{0 . 3 2 5}$ & 0.000 \\
\hline & & & & & $t=-0.074$ & 0.001 \\
\hline & $\mathrm{T}, \mathrm{t}, \mathrm{T} * \mathrm{t}$ & & 2098.97 & 63.56 & $\mathrm{~T}=-257$ & 0.000 \\
\hline & & & & & $t=-0.051$ & 0.003 \\
\hline & & & & & $\mathrm{T} * \mathrm{t}=.020$ & 0.084 \\
\hline \multirow[t]{5}{*}{$P$. pinaster } & $\mathbf{T}$ & 1950.67 & 1532.42 & 88.11 & $T=-0.410$ & 0.000 \\
\hline & $\mathrm{T}, \mathrm{t}$ & & 1515.92 & 88.10 & $\mathrm{~T}=-0.365$ & 0.000 \\
\hline & $\mathrm{T}, \mathrm{t}, \mathrm{T}^{*} \mathrm{t}$ & & 151095 & 8810 & $\begin{array}{l}\mathrm{T}=-0.080 \\
\mathrm{~T}\end{array}$ & 0.000 \\
\hline & & & & & $\mathrm{t}=0$ & 0.521 \\
\hline & & & & & $\mathrm{T}^{*} \mathrm{t}=-0.037$ & 0.0301 \\
\hline
\end{tabular}

T, Temperature; $t$, exposure time. $-2 \mathrm{LL}$ (constant) is the $-2 \log$ likelihood value of the model including only the constant. Models in bold are the selected ones - see figure 2 . The coefficients of the variables in italics are not significantly different from 0 .

pioneers, not only associated with fire, but also with colonizing disturbed areas free of competitors $[32,44,53$, 62]. In this context, physical dormancy of hard-coated seeds can be broken by fire because of the desiccation of the seed coat [9] but not exclusively $[5,6]$. Thus, although seed germination is enhanced by heat shock, germination can also be triggered by any perturbation able to alter the seed coat $[5,6]$. This is a widely spread 

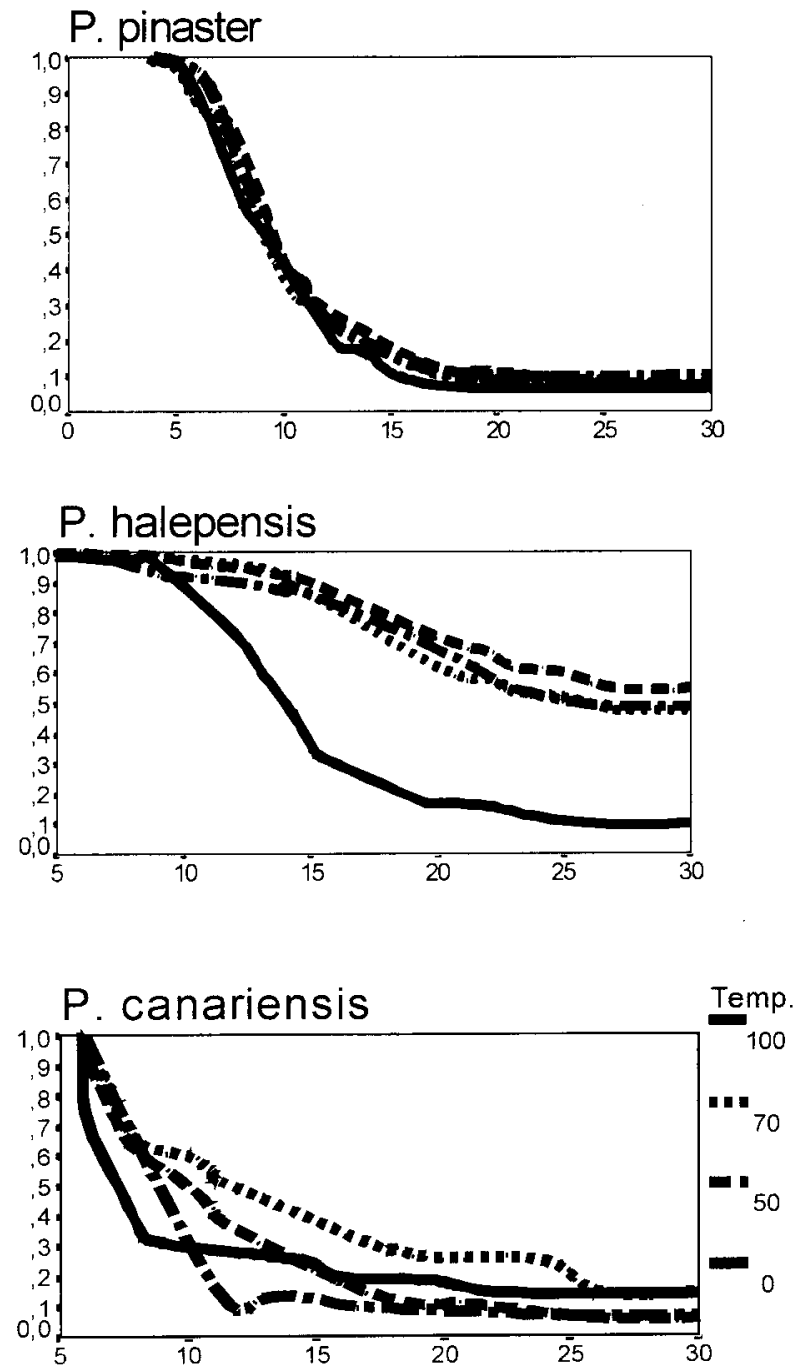

Figure 1. Shape of the germination curves for the less severe treatments (Kaplan-Meier model) expressed as the fraction of seeds not germinated. Three different patterns have been detected: 1) Curves do not show significant differences (logrank test, $P>0.05$ ) between them ( $P$. pinaster $) .2)$ Seeds at control conditions germinate significantly faster, whereas the rest are not significantly different (i.e. P. halepensis). 3) Curves after different treatments follow complex patterns (i.e. $P$. canariensis).

strategy in colonizers adapted to very fluctuating environments such as those of Mediterranean ecosystems [50].

Pine seeds are ready to germinate (germinability above $75 \%$ in all of them at control) in contrast to seeds from typical Mediterranean shrubs, which present a deep dormancy based on coat hardness and impermeability [7, $13,43,55]$. This fact suggests that pine adaptation to perturbations must be sustained not in dormancy characteristics or structural properties that prevent immediate germination of seeds as is usual in Mediterranean plants $[7,8,24,56]$, but in other adaptive responses.

As suggested by the differences between germination models, the adaptive traits of each pine species may be specific. Thus, the germination behaviour after heat treatment of two of the Spanish lowland pines $(P$. halepensis, $P$. pinaster) is considerably different in spite of the fact that their establishment is based on a very similar powerful light-induced regenerative capacity [51, 58 , a yearly production of prolific seed crops and the safe-guarding of large canopy seed banks [29] as shown by Daskalakou and Thanos [14] in P. halepensis.

Germination of $P$. pinaster seems to be mainly controlled by the temperature and not by the exposure time, reaching values of probability of germination below 0.5 only when temperature surpasses $130^{\circ} \mathrm{C}$ (figure 2). This suggests that seed cover confers a resistance over a wide range of fire intensities, failing only when high temperatures are reached [36]. This fact agrees with the lack of significant differences (log-rank test) between the germination curves after the less severe treatments (figure 1) Thus, the recruitment of this pine after wildfires seems to be assured by the combination of coat resistance and cone protection and not by the existence of a large soil seed bank, since seed longevity is barely more than 2 years [36]. The low germinability obtained by Reyes and Casal [46] might be a consequence of a fast viability loss of stored seeds $[11,12]$. On the other hand, $P$. halepensis which had been considered primarily as a genuine pyrophyte $[28,30,59]$, has severe problems in germinating after heat treatment. In this case, seed cover confers a weaker protection and the exposure time becomes relevant (figure 2). A temperature around $70{ }^{\circ} \mathrm{C}$ could determine the failure of the seed if the exposure time is higher than $10 \mathrm{~min}[14,36]$. However, postfire recruitment is always very effective even after very intense fires [41, 35, 54]. Daskalakou and Thanos [14] suggested that the efficient postfire regeneration of $P$. halepensis must first depend upon a high canopy seed bank because seeds found in the soil are killed and those stored in cones are efficiently protected. Furthermore, dissemination from seeds of edge surviving pines is very limited $[2,47]$. Thus, though seed mortality can become very important in some wildfires as also shown for our models, a significant number of seeds should survive [49]. After that, early seedling establishment is well adapted to exploit the postfire conditions [64]. Another problem related to fire disturbances arises after comparing the curves of germination: control seeds are faster to 

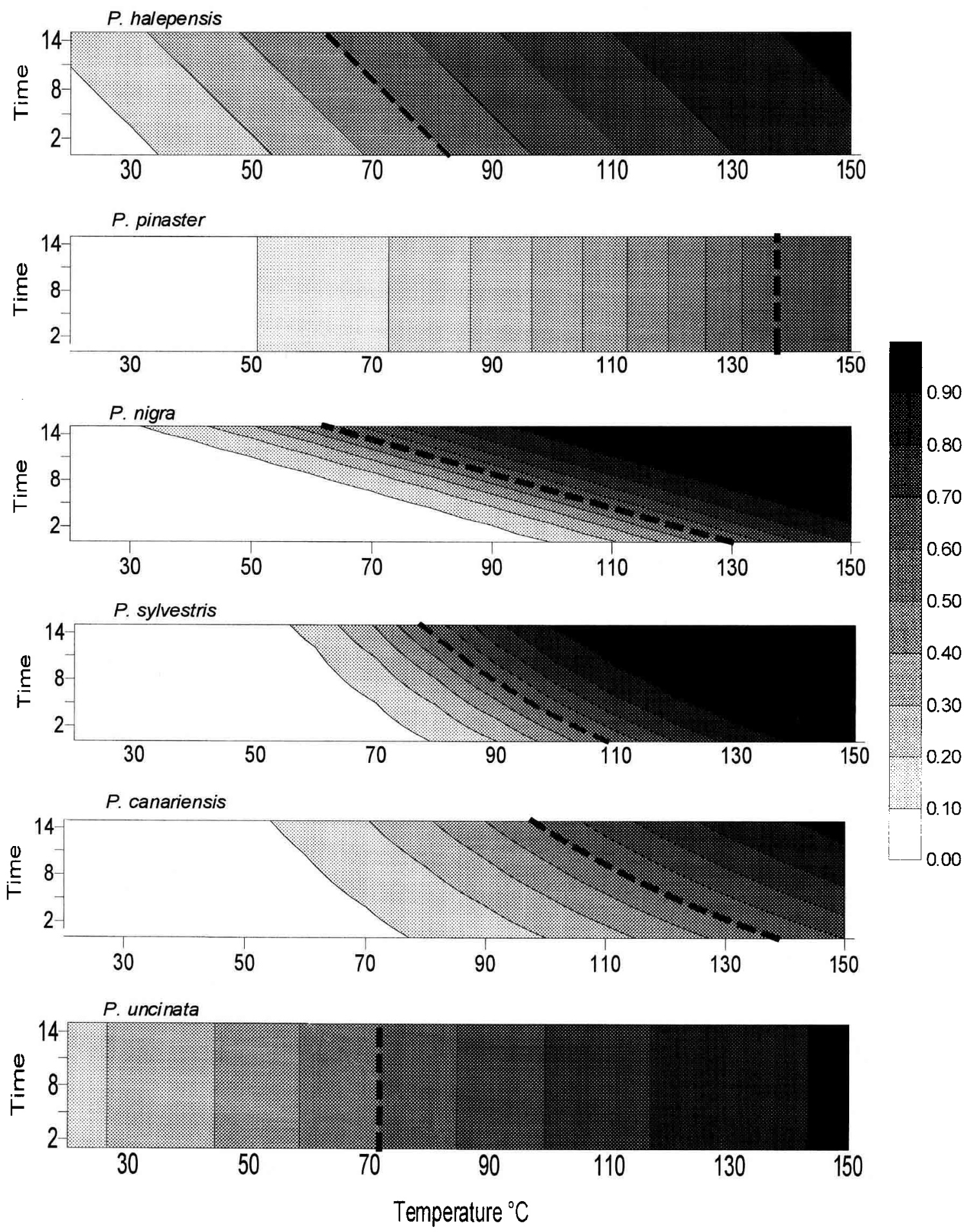

Figure 2. Contour maps of the probability of germination in temperature by exposure time space. Selected models are shown in bold in table $I$. X-axis is the temperature and $y$-axis is the exposure time during the fire intensity treatments. The isoline of 0.5 probability is in bold, seeds submitted to treatments located to the right of this line have no chance of germination. 
germinate than those submitted to fire intensity treatments (figure 1). Probably, seeds need more time to complete their imbibition after desiccation, and so predation risk by granivorous birds could be increased [49].

Seed behaviour of the third Spanish lowland pine, $P$. pinea, is completely different. Germination percentage is similar after almost all the treatments, a significant decay being detected only after the most severe one $\left(130^{\circ} \mathrm{C} / 3\right.$ $\min )$. The seed size is one of the highest in the genus [11]. Thus, this pinyon pine has been widely planted for its edible seeds. The seed weight is $0.70 \mathrm{~g} \pm 0.12$ $(n=200)$ and length $1.68 \mathrm{~cm} \pm 0.14$, which is considerably higher than in $P$. canariensis: weight, $0.12 \mathrm{~g} \pm 0.03$ and length, $1.11 \mathrm{~cm} \pm 0.13 ; n=200$ ). These results seem to support the idea exposed by Keeley [22] and Reyes and Casal [46] that larger seeds are more resistant to fire. Then, larger seed size might have evolved not only in relation to dispersal and to secure survival of seedlings, but also as a response to wildfire. This idea should be tested, both intra- and interspecifically. Furthermore, seeds of $P$. pine $a$ are wingless, dispersing only under the canopy of parent trees, and do not require light to germinate [51]. Thus, recruitment after fire disturbance should be a rare event which is controlled by the high fire resistance of $P$. pinea seeds.

Montane pines also show problems in germinating after heat treatment (figure 2). In a recent paper, we commented on the implications at the community level of this behaviour [15]. As also shown by Trabaud and Campant [63] recruitment of $P$. nigra after catastrophic wildfires can become cumbersome. Natural forests of these trees ( $P$. nigra, $P$. sylvestris and $P$. uncinata) appear on the oro-Mediterranean and sub-Alpine belts of the highest mountain of the eastern half of the Peninsula or on rocky sites at lower altitudes, such as spurs, crests and step slopes [42]. In such situations, tree population structure results in a patchy distribution of trees, surrounded by a general matrix of creeping scrubs, caespitose grasses and bare rock outcrops. At these conditions, wildfire is rarely catastrophic and many trees can easily survive. It is probably for this reason that these pines base their dispersal strategy on small seeds more easily dispersed by wind $(P$. sylvestris: weight, $0.01 \mathrm{~g} \pm 0.005$, $P$. uncinata: $0.01 \mathrm{~g} \pm 0.01$ and $P$. nigra: $0.02 \mathrm{~g} \pm 0.01$; $n=200$ ). Thus, pine recruitment in the postfire environment seems to be secured from surviving pines.

The detected problems $[15,63]$ and the high incidence of fires of more than 10000 ha $[37,68]$ on the extensive pine forests of $P$. sylvestris and $P$. nigra located at lower altitudes on deeper soils (supra-Mediterranean and montane belts) is most likely due to landscape homogenization resulting from a decrease in man-driven disturbances [3]. Thus, after wildfires almost all seeds die.
Dispersion from surviving edge pines is strongly limited because the size of the burnt areas are very important [47, 54]. Consequently, resprouters such as different Quercus species which are usually interspersed in the subcanopy can rapidly control the available space [12]. These events may determine notorious landscape changes and pines can become locally extinct.

Anyway, these pines also show some differences in their germination responses after high temperature treatment. $P$. uncinata germinability is highly sensitive to heat treatment, whilst indifferent to the exposure time. A temperature above $70{ }^{\circ} \mathrm{C}$ may kill the seeds even after a short period (figure 2). The germination behaviours of $P$. sylvestris and $P$. nigra are similar. Seed cover confers protection on the embryo in a very narrow range of temperatures. Even low temperatures $\left(50-70{ }^{\circ} \mathrm{C}\right)$ can cause the seeds to not germinate after $10-15 \mathrm{~min}$.

Finally, the strategy of the Canarian pine is different. Whereas most pines regenerate by seeds alone because adult plants are killed by fire - obligate seeders, $P$. canariensis is capable of using seeds or resprouts to recover from wildfires. Mature seeds germinate without restriction at control conditions and they can also germinate at lower heat temperatures, the exposure time not being relevant. However, at higher temperatures, a longer time exposure induces seed death (figure 2). In any case, only field experiments can lead us to determine the role of seeds in the regeneration of a natural Canarian pine forest.

\section{Conclusions}

Whereas most of the Mediterranean seeders base their efficient recruitment after wildfires on the presence of hard-coated seeds, Mediterranean pines have attempted other 'strategies' with some variants. They have chosen another solution related to prolific seed production. Seeds germinate readily without treatment, losing their viability in short periods and only show a slight protection from fire, with most of them being killed. Thus, lowland pines, such as $P$. halepensis and $P$. pinaster, based recruitment in the postfire environment on the existence of a large canopy seed bank and a certain degree of serotiny [14] because thermophilous pine forests are really fire-prone systems; cones of up 20 years of age contained a considerable fraction of germinable seeds in $P$. halepensis [14]. As shown by Fraver [16] the temperature transmission into cones is not very intense, so some of the seeds can survive and be released to the soil after wildfire. However, $P$. pinea and partially also $P$. pinaster, based their re-establishment strategy after fire on the presence of a very resistant hard coat 
which confers protection in a wide range of temperatures. On the other hand, montane pines ( $P$. uncinata, $P$. nigra and $P$. sylvestris) based their re-establishment on the landscape heterogeneity and a more efficient dispersal strategy, sustaining their stand regeneration by surviving trees. Finally, the coincidence of prolific crops and resprouting in $P$. canariensis might have evolved as a response to low mean fire intervals and the necessity to exploit new bare territories, both of which are related to the intense volcanic activity of the Canary Islands.

In spite of the fact that all pines occur in fire-prone environments, it is clear that their germination syndromes have not evolved in relation to wildfire alone. Furthermore, seed behaviour is not related to the general syndromes described by Keeley [23] as being typical of fire-evolved plants. This author points out that species that germinate readily without treatments are usually resprouters, which is not the case here, except for $P$. canariensis.

Acknowledgements We would like thank to Dr Rubio of E.T.S.I. Montes (U.P.M.), Dr G. Aussenac (Inra-Nancy) and anonymous reviewers for their valuable comments, and Jesús Andrés for his linguistic assistance. This research was financed by the CAM project no. 06M/003/96 and the project PB96-0004 of the Spanish Ministry of Education.

\section{References}

[1] Abbas H., Barbero H., Loisel R., Réflexions sur le dynamisme actuel de la régéneration naturelle du pin d'Alep (Pinus halepensis Mil.) dans les pinèdes incendiées en Provence calcaire (de 1973 à 1979), Ecol. Medit. 10 (1984) 85-95.

[2] Acherar M., Lepart J., Debussche M., La colonitation des friches par le pin d'Alep (Pinus halepensis Mill) en Languedoc méditerranéen, Acta Oecol. 19 (1984) 179-189.

[3] Barbero M., Bonin G., Loisel R.F., Quézel P., Changes and disturbances of forest ecosystems caused by human activities in the western part of the Mediterranean basin, Vegetatio 87 (1990) 151-173.

[4] Barbero M., Quézel P., Structures, architectures forestiéres á sclérophylles et prévention des incendies, Bull. Ecol. 2 (1989) 7-14.

[5] Baskin J.M., Baskin C.C., Physiology of dormancy and germination to seed bank ecology, in: Leck M.A., Parker V.T., Simpson R.L. (Eds.), Ecology of Soil Seed Banks, Academic Press, San Diego, 1989, pp. 55-56.

[6] Baskin J.M., Baskin C.C., Seeds. Ecology, Biogeography and Evolution of Dormancy and Germination, Academic Press, San Diego, 1998.
[7] Bell D.T., Plummer J.A., Taylor S.K., Seed germination ecology in southwestern and western Australia, Bot. Rev. 59 (1993) 24-73.

[8] Bell D.T., Rokich D.P., McChesney C.J., Plummer J.A., Effects of temperature, light and gibberelic acid on the germination of seeds of 43 species native to western Australia, J. Veg. Sci. 6 (1995) 797-806.

[9] Brits G.J., Calitz F.J., Brown N.A.C., Manning, Desiccation as the active principle in heat-stimulated seed germination of Leucospermum R. Br. (Proteaceae) in fynbos, New Phytol. 125 (1993) 397-403.

[10] Castro J.F., Bento J., Rego F., Regeneration of Pinus pinaster forests after wildfire, in: Goldammer J.G., Jenkins M.J. (Eds.), Fire in Ecosystem Dynamics, SPB Academic Publishing, The Hague, 1990, pp. 71-75.

[11] Catalán G., Semillas de Arboles y Arbustos Forestales. Ministerio de Agricultura, Pesca y Alimentación, Madrid, 1985.

[12] Ceballos L., Ruiz de la Torre J., Arboles y Arbustos de la España Peninsular, Escuela Técnica Superior de Ingenieros de Montes, Universidad Politécnica de Madrid, Madrid, 1971.

[13] Corral R., Pita J.M., Pérez-García F., Some aspects of seed germination in four species of Cistus L., Seed Sci. Technol. 18 (1990) 321-325.

[14] Daskalakou E.N., Thanos C.A., Aleppo pine (Pinus halepensis) postfire regeneration: the role of canopy and soil seed banks, Int. J. Wildland Fire 6 (1996) 59-66.

[15] Escudero A., Barrero S., Pita J.M., Effects of high temperatures and ash on seed germination of two Iberian pines (Pinus nigra ssp. salzmannii, P. sylvestris var iberica), Ann. Sci. For. 54 (1997) 553-562.

[16] Fraver S., The insulating value of serotinous cones in protecting pitch pine (Pinus rigida) seeds from high temperatures, J. PA Acad. Sci. 65 (1992) 112-116.

[17] García-Plé C., Vanrell P., Morey M., Litter fall and decomposition in a Pinus halepensis forest on Mallorca, J. Veg. Sci. 6 (1995) 117-22.

[18] González-Rabanal F., Casal M., Effect of high temperatures and ash on germination of ten species from gorse shrubland, Vegetatio 116 (1995) 123-131.

[19] Hauck W.W., Donner A., Wald's test as applied to hypotheses in logit analysis, J. Am. Stat. Assoc. 72 (1977) 851-853.

[20] Hosmer D.W. Jr., Lemeshow S., Applied Logistic Regression, John Wiley \& Sons, New York, USA, 1989.

[21] James F.C., McCulloch C.E., Multivariate analysis in ecology and systematics: Panacea or Pandora's box, Annu. Rev. Ecol. Syst. 21 (1990) 129-166.

[22] Keeley J., Seed production, seed populations in soil, and seedling production after fire for 2 congeneric pairs of sprouting and non-sprouting chaparral shrubs, Ecology 58 (1977) 820-829.

[23] Keeley J., Role of fire in seed germination of woody taxa in California chaparral, Ecology 68 (1987) 434-443.

[24] Keeley J.E., Seed germination and life syndromes in California chaparral, Bot. Rev. 57 (1991) 81-116. 
[25] Keeley J., Bond W.J., Convergent seed germination in South African fynbos and Californian chaparral, Plant Ecol. 133 (1997) 153-167.

[26] Keeley J.E., Keeley S.C., Role of fire in the germination of chaparral herbs and suffrutescents, Madroño 34 (1987) $240-249$.

[27] Kleinbaum D.G., Logistic Regression: a Self Learning Text, Springer Verlag, New York, USA, 1994.

[28] Kuhnholtz-Lordat G., L’écrant vert, Memoires de Muséum national d'histoire naturelle, Série B 9, París, 1958.

[29] Lamont B.B., Le Maitre D.C., Cowling R.M., Enright N.J., Canopy seed storage in woody plants, Bot. Rev. 57 (1991) 277-317.

[30] Le Houérou H.N., Fire and vegetation in the Mediterranean Basin, Tall Timbers Fire Ecology Conference 13 (1974) 237-277.

[31] Loisel R., Germination du pin d'Alep au niveau de certaines associations végétales de Basse-Provence, Bull. Soc. Bot. Fr. 113 (1966) 324-330.

[32] Luis-Calabuig E., Tárrega R., Alonso I., Seedling regeneration of two Cistus species after experimental disturbances, Int. J. Wildland Fire 6 (1996) 13-19.

[33] Malanson G.P., Intensity as a 3rd factor of disturbance regime and its effects on species diversity, Oikos 43 (1984) $411-413$.

[34] Malo J., Suárez F., Cistus ladanifer recruiment - not only fire but also deer, Acta Oecol. 17 (1996) 55-60.

[35] Mansanet C.M., Incendios Forestales en Alicante, Estudio de la Evolución de la vegetación Quemada, Caja de Ahorros Provincial, Alicante, 1987.

[36] Martínez-Sánchez J.J., Marín A., Herranz J.M., Ferrandis P., De las Heras J., Effects of high temperatures on germination of Pinus halepensis Mill. and P. pinaster Aiton subsp. pinaster seeds in southeast Spain, Vegetatio 116 (1995) 69-72.

[37] Moreno J.M., Vázquez A., Pérez B., Faraco A.M., Fernández-Gonzaléz F., Quintana J.R., Cruz A., Los incendios forestales en España y su impacto sobre los ecosistemas: lecciones del estudio de los montes de Gredos, Avances en Fitosociología (1996) 23-42.

[38] Naveh Z., The evolutionary significance of fire in the Mediterranean Region, Vegetatio 29 (1975) 199-298.

[39] Naveh Z., Fire in the Mediterranean - a landscape ecological perspective, in: Goldammer J.G., Jenkins M.J. (Eds.), Fire in Ecosystems Dynamic, SPB Academic Pub., The Hague, The Netherlands, 1990, pp. 1-20.

[40] Naveh Z., The role of fire and its management in conservation of Mediterranean ecosystem and landscapes, in: Moreno J.M., Oechel W.C. (Eds.), The Role of Fire in Mediterranean-Type Ecosystems, Springer Verlag, Berlin, 1994, pp. 163-186.

[41] Papió C., Regeneració del pi blanc despres d'un incendi, Quaderns Ecologia Aplicada 10 (1987) 83-91.

[42] Peinado M., Rivas-Martínez S., La Vegetación de España, Publicaciones Universidad de Alcalá de Henares, Madrid, 1987.
[43] Pérez-García F., Escudero A., Role of the seed coat in the germination of Cistus populifolius L., Isr. J. Plant Sci. 45 (1998) 44-48.

[44] Pugnaire F.Y., Lozano J., Effects of soil disturbance, fire and litter accumulation on the establishment of Cistus clusii seedlings, Plant Ecol. 131 (1997) 207-213.

[45] Pyke D.A., Thompson J.N., Statistical analysis of survival and removal rate experiments, Ecology 67 (1986) $240-245$.

[46] Reyes O., Casal M., Germination behavior of 3 species of the genus Pinus in relation to high temperatures suffered during forest fires, Ann. Sci. For. 52 (1995) 385-392.

[47] Richardson D.M., Age structure and regeneration after fire in a self-sown Pinus halepensis forest on the Cape Peninsula, South Africa, S. Afr. J. Bot. 54 (1988) 140-144.

[48] Rivas-Martínez S., Memoria del Mapa de Series de Vegetación de España, Ministerio de Agricultura, Pesca y Alimentación, Madrid, 1987.

[49] Saracino A., Pacell R., Leone V., Borghetti M., Seed dispersal and changing seed characteristics in a Pinus halepensis Mill. forest after fire, Plant Ecol. 130 (1997) 13-19.

[50] Silvertown J.W., Phenotypic variety in seed germination behaviour: the ontogeny and evolution of somatic polymorphism in seeds, Am. Nat. 124 (1984) 1-16.

[51] Skordilis A., Thanos C.A., Seed stratification and germination strategy in the Mediterranean pines Pinus brutia and P. halepensis, Seed Sci. Res. 5 (1995) 151-160.

[52] Tárrega R., Calvo L., Trabaud L., Effect of high temperatures on seed germination of two woody leguminosae, Vegetatio 102 (1992) 139-147.

[53] Tárrega R., Luis-Calabuig E., Alonso I., Space-time heterogeneity in the recovery after experimental burning and cutting in a Cistus laurifolius shrubland, Plant Ecol. 129 (1997) 179-187.

[54] Thanos C.A., Daskalakou E.N., Nikolaidou S., Early postfire regeneration of a Pinus halepensis forest at Mt. Parnes, Attica, Greece, J. Veg. Sci. 7 (1996) 273-280.

[55] Thanos C.A., Georghiou K., Ecophysiology of the firestimulated seed germination in Cistus incanus ssp. creticus (L.) Heywood and C. salvifolius L., Plant Cell Environ. 11 (1988) 841-849.

[56] Thanos C.A., Georghiou K., Kadis C., Pantazi C., Cistaceae: a family with hard seeds, Isr. J. Bot. 41 (1992) 251-263.

[57] Thanos C.A., Marcou S., Christodoulakis D., Yannitsaros A., Early post-fire regeneration in Pinus brutia forest ecosystems of Samos island (Greece), Acta Oecologica Oecol. Plant. 10 (1989) 79-94.

[58] Thanos C.A., Skordilis A., The effects of light, temperature and osmotic stress on the germination of Pinus halepensis and $P$. brutia seeds, Seed Sci. Technol. 15 (1987) 163-174.

[59] Trabaud L., Quelques valeurs et observations sur la phytodynamique des surfaces incendiées dans le BasLanguedoc, Nat. Monspeliensia Bot. 21 (1970) 231-242. 
[60] Trabaud L., Dynamics after fire of sclerophyllous plant communities in the Mediterranean basin, Ecol. Medit. 13 (1987) 25-37.

[61] Trabaud L., Post-fire community dynamics in the Mediterranean basin, in: Moreno, J.M., Oechel W.C. (Eds.), The Role of Fire in Mediterranean-Type Ecosystems, SpringerVerlag, Berlin, 1994, pp. 1-15,

[62] Trabaud L., Modalités de germination des cistes et des pins méditerranéens et colonisation des sites perturbés, Rev. Ecol. (Terre Vie) 50 (1995) 3-14.

[63] Trabaud L., Campant C., Difficulté de recolonisation naturelle du pin de Salzmann Pinus nigra Arn. ssp. salzmannii (Dunal) Franco aprés incendie, Biol. Conserv. 58 (1991) 329-343.

[64] Trabaud L., Michels C., Grosman J., Recovery of burnt Pinus halepensis Mill. forests. II. Pine reconstitution after wildfire, For. Ecol. Manag. 13 (1985) 167-179.
[65] Trabaud L., Oustric J., Influence du feu sur la germination des semences de quatre espéces ligneuses méditerranéennes á reproduction sexuée obligatoire, Seed Sci. Technol. 17 (1989) 589-599.

[66] Trabaud L., Oustric J., Heat requirements for seed germination of three Cistus species in the garrigue of Southern France, Flora 183 (1989) 321-325.

[67] Trexler J.C., Travis J., Nontraditional regression analyses, Ecology 74 (1993) 1629-1637.

[68] Vázquez A., Moreno J.M., Sensivity of fire occurrence to meteorological variables in Mediterranean and Atlantic areas of Spain, Landsc. Urban Plann. 24 (1993) 129-142.

[69] Vuillemin J., Bulard C., Écophysiologie de la germination de Cistus albidus L. et Cistus monspeliensis L., Nat. Monspeliensia Bot. 46 (1981) 1-11.

Appendix 1. Number of germinated seeds in each treatment.

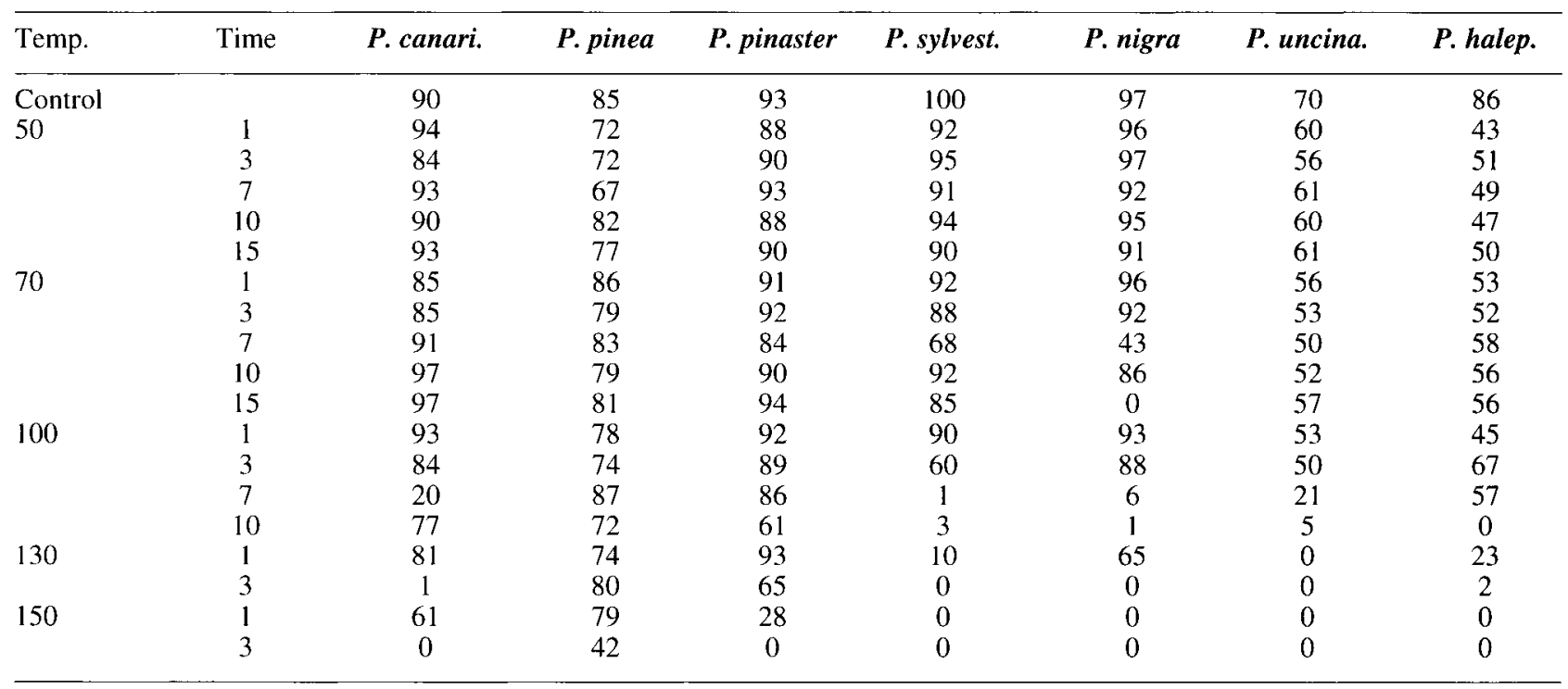

